\title{
Asam Lemak Bebas dan Angka Peroksida pada Minyak Kelapa Hasil OlahanTradisional dan Hasil Olahan dengan Penambahan Saccharomyces cereviseae
}

\section{Free Fatty Acid Level and Peroxide Value in Coconut Oil Traditional Processed and Addition Processed Saccharomyces cereviseae}

\author{
Ragas Fitria Sina Murti ${ }^{1}$, Nur Hidayati ${ }^{2}{ }^{*}$, dan Mardiyono ${ }^{3}$ \\ ${ }^{1,2}$ Program Studi D III Analis Kesehatan Fakultas Ilmu Kesehatan, Universitas Setia Budi Surakarta \\ ${ }^{3}$ Program Studi S1 Farmasi Fakultas Farmasi, Universitas Setia Budi Surakarta \\ *Corresponding author : nurhidayati.nh@gmail.com
}

\section{ABSTRAK}

Minyak merupakan zat makanan yang penting untuk menjaga tubuh manusia, dan juga merupakan sumber energi yang efektif dibandingkan dengan karbohidrat dan protein. Minyak mempunyai nilai ekonomi yang tinggi dan dikenal secara luas sebagai medium pengahantar panas, menambah cita rasa, gizi dan aroma dalam menggoreng. Pengujian kualitas minyak tersebut diantaranya dengan menentukan kadar asam lemak bebas dan angka peroksida.

Penelitian ini bertujuan untuk mengetahui besarnya kadar asam lemak bebas dan angka peroksida pada minyak kelapa hasil olahan tradisional dan hasil olahan dengan penambahan Saccharomyces cerevisiae (konsentrasi 0\%, 2\%, $4 \%, 6 \%$, dan $8 \%$ ).

Hasil penelitian ini diperoleh kadar asam lemak bebas pada minyak kelapa hasil olahan tradisional $=0,95 \%$ dan kadar asam lemak bebas pada minyak kelapa hasil olahan dengan penambahan Saccaromyces cerevisiae (konsentrasi $0 \%, 2 \%, 4 \%, 6 \%$, dan $8 \%)$ berturut-turut adalah $(0,71 \%, 0,63 \%, 0,62 \%, 0,57 \%$, dan 0,50\%). Sedangkan angka peroksida pada minyak kelapa hasil olahan tradisional $=0,88 \mathrm{mg}$ oksigen $/ 100 \mathrm{~g}$ bahan dan angka peroksida pada minyak kelapa hasil olahan dengan penambahan Saccaromyces cerevisiae (konsentrasi 0\%, 2\%, 4\%, 6\%, dan 8\%) berturut-turut adalah $(0,80 ; 0,68 ; 0,61 ; 0,50$; dan 0,44 mg/100 g bahan). Kedua minyak tersebut memenuhi syarat SNI 7381:2008.

Kata kunci : Asam Lemak Bebas dan Angka Peroksida, Minyak Kelapa, Saccharomyces cerevisiae.

\section{ABSTRACT}

Oil is essential nutrient to take care of the human body, and also effective source of energy than carbohydrate and protein. Oil have high economic value and known as medium of heat conductor, increase flavor, nutrition and aroma in frying. The testingof oil quality amongthem isdetermine free fatty acidlevel and peroxide level.

The aims of this study to determine free fatty acid level and peroxide levelin traditional coconut oil processed and processed with Saccharomyces cerevisiaeaddition (concentrations $0 \%, 2 \%, 4 \%, 6 \%$, and $8 \%$ ).

The resultsobtained that free fatty acid level in traditional coconut oilprocessed $=0.95 \%$ and free fatty acid level in coconut oil processed with addition of Saccaromyces cerevisiae (concentrations $0 \%, 2 \%, 4 \%, 6 \%$, and $8 \%$ ) were $(0.71 \%$, $0.63 \%, 0.62 \%, 0.57 \%$, and $0.50 \%)$ respectively. Meanwhile, peroxide level of traditional coconut oil processed $=0.88 \mathrm{mg}$ oxygen/100 g material and peroxide levelincoconut oil processedwith addition of Saccaromyces cerevisiae (concentrations $0 \%, 2 \%, 4 \%, 6 \%$, and $8 \%$ ) were $(0.80 ; 0.68 ; 0.61 ; 0.50$, and $0.44 \mathrm{mg} / 100 \mathrm{~g}$ material) respectively. Both oils were meet the requirement of ISO 7381:2008.

Keywords : Free Fatty Acid Level and Peroxide Value, Coconut Oil, Saccharomyces cerevisiae

\section{PENDAHULUAN}

Minyak kelapa berasal dari daging buah kelapa (Cocos nucifera L.) yang dapat diproses secara kering dan secara basah. Minyak kelapa hasil proses kering digunakan untuk bahan dasar berbagai macam industri seperti sabun dan margarin dengan atau tanpa proses pemurnian. Minyak kelapa hasil proses basah hampir selalu dipergunakan untuk minyak goreng.

Minyak merupakan salah satu kebutuhan pokok manusia. Minyak nabati di antaranya minyak kelapa, minyak kelapa sawit, minyak 
biji-bijian, minyak kedelai dan sebagainya.

Pengolahan minyak kelapa telah dilakukan oleh masyrakat dengan cara memanaskan santan kelapa sampai diperoleh minyak dan blondo, cara ini sering disebut dengan cara tradisional (Rindengan dan Novarianto. 2005).

Melalui berbagai penelitian juga ditemukan bahwa minyak yang dihasilkan dengan cara fermentasi memiliki mutu yang lebih baik menurut SNI dibandingkan dengan minyak hasil masak langsung. Untuk meningkatkan efisiensi pembuatan minyak telah dikembangkan berbagai cara pembuatan minyak kelapa secara fermentasi dengan bahan baku santan dan menggunakan mikroorganisme. Keuntungan lain dari pembuatan minyak dengan carra fermentasi adalah tidak membutuhkan bahan bakar yang cukup banyak (Rindengan dan Novarianto, 2005). Mikroba yang dapat digunakan pada penelitian ini adalah Saccharomyces cereviseae. Khamir Saccharomyces cereviseae dapat menghasilkan enzim proteolitik dan amilolitik.

Penelitian ini bertujuan untuk mengetahui apakah ada perbedaan kadar asam lemak bebas dan angka peroksida pada minyak kelapa hasil olahan tradisional dan hasil olahan dengan khamir Saccharomyces cereviseae (konsentrasi $0 \%, 2 \%, 4 \%, 6 \%$, dan $8 \%$ ) dan kualitas minyak ditinjau dari standard mutu minyak kelapa dari SNI 7381:2008. Sehingga dapat memberikan informasi kepada masyarakat mengenai minyak kelapa yang dibuat dengan pe-nambahan Saccharomyces cereviseae mampu menghasilkan produk yang bernilai ekonomis.

\section{METODE PENELITIAN}

\section{Sampel}

Sampel pada penelitian adalah minyak kelapa hasil olahan tradisional dan hasil olahan dengan penambahan Saccharomyces cerevisiae dengan variasi konsentrasi $0 \%, 2 \%, 4 \%, 6 \%$, dan $8 \%$, selanjutnya ditentukan kadar asam lemak bebas dan angka peroksidanya.

\section{Cara Pembuatan Minyak Kelapa Fermen- tasi dengan Saccharomyces cerevisiae}

1. Santan kelapa dan air dengan perbanding-an (4:1), dimasukkan ke dalam wadah plastik.

2. Dimasukkan khamir Saccharomyces cereviseae dengan variasi konsentrasi: $0 \%, 2 \%$, $4 \%, 6 \%, 8 \%$.

3. Selanjutnya santan yang sudah dicampur dengan Saccharomyces cereviseae disimpan pada suhu kamar selama \pm 8 jam.

4. Proses penyimpanan menghasilkan 3 lapisan yaitu minyak, padatan/krim dan skim. Selanjutnya krim dipisahkan dari skimnya.

5. Krim dipanaskan sampai membentuk blondo dan minyak, kemudian minyak dipisahkan dan ditimbang.

6. Minyak yang diperoleh selanjutnya dianalisis kualitas di antaranya kadar asam lemak bebas dan angka peroksida

7. Menghitung kadar Asam Lemak Bebas dengan rumus:

Asam Lemak Bebas (\%) $=\frac{\mathrm{ml} \times \mathrm{N} \mathrm{NaOH} \times \text { BM As. Lemak }}{\text { Berat Bahan (g) } \times 1000} \times 100 \%$ $\mathrm{N}=$ Normalitas $\mathrm{NaOH}$

8. Menghitung Angka Peroksida dengan rumus:

$$
\text { Angka peroksida }=\frac{\mathrm{ml} \times \mathrm{N} \mathrm{Na}-\text { Thiosulfat }}{\text { berat bahan }(\mathrm{g})} \times 1000
$$

(Ketaren, 2016).

9. Kadar asam Lemak Bebas dan Angka Peroksida yang diperoleh distandarkan dengan SNI 7381:2008

Asam Lemak Bebas maksimum 5\% dan Angka Peroksida maksimum $2 \mathrm{mg}$ oksigen/g contoh.

\section{Skema Penelitian :}

Skema Penelitian pembuatan minyak kelapa secara tradisional dan dengan cara fermentasi menggunakan khamir Saccharomyces cereviseae dengan variasi konsentrasi $0 \%, 2 \%$, 4\%,6\%,8\%. disajikan pada Gambar 1 .

\section{HASIL DAN PEMBAHASAN Hasil Penelitian}

Berdasarkan hasil penelitian yang dilaku- 


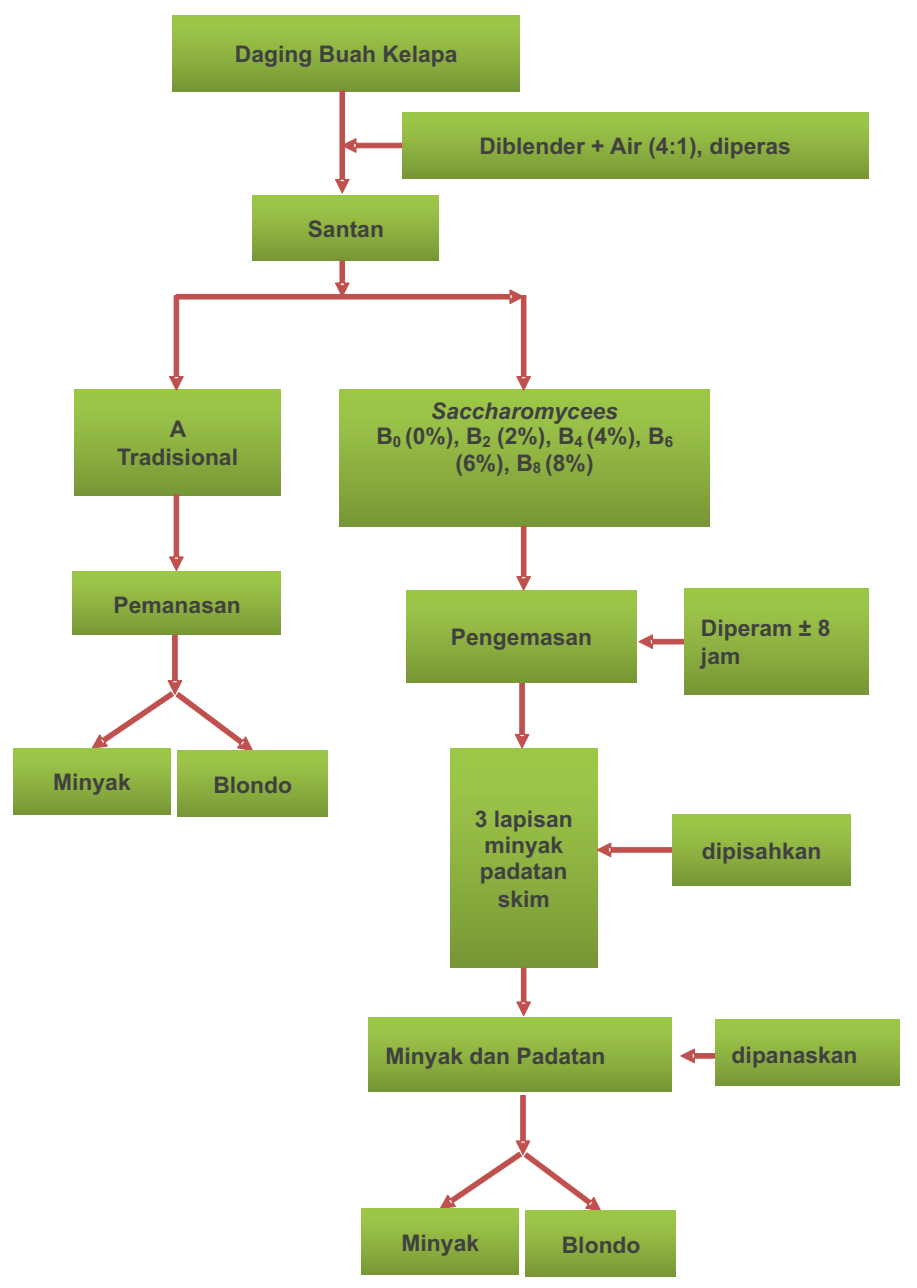

Gambar 1. Skema Penelitian

Tabel 1. Pengamatan Organoleptis Minyak Kelapa

\begin{tabular}{|c|c|c|c|c|c|c|}
\hline $\begin{array}{c}\text { Parameter } \\
\text { Uji }\end{array}$ & $\mathbf{A}$ & $\mathbf{B}_{\mathbf{0}}$ & $\mathbf{B}_{\mathbf{2}}$ & $\mathbf{B}_{\mathbf{4}}$ & $\mathbf{B}_{\mathbf{6}}$ & $\mathbf{B}_{\mathbf{8}}$ \\
\hline Bentuk & Cair & Cair & Cair & Cair & Cair & Cair \\
\hline Warna & $\begin{array}{c}\text { Kuning } \\
\text { pucat }\end{array}$ & $\begin{array}{c}\text { Kuning } \\
\text { muda }\end{array}$ & $\begin{array}{c}\text { Kuning } \\
\text { muda }\end{array}$ & $\begin{array}{c}\text { Kuning } \\
\text { muda }\end{array}$ & $\begin{array}{c}\text { Kuning } \\
\text { muda }\end{array}$ & $\begin{array}{c}\text { Kuning } \\
\text { muda }\end{array}$ \\
\hline Bau & $\begin{array}{c}\text { Agak } \\
\text { harum }\end{array}$ & Harum & Harum & Harum & Harum & Harum \\
\hline Rasa & $\begin{array}{c}\text { Agak } \\
\text { gurih }\end{array}$ & Gurih & Gurih & Gurih & Gurih & Gurih \\
\hline
\end{tabular}

Keterangan :

Sampel A : Minyak kelapa hasil olahan tradisional

Sampel B0-B8 : Minyak kelapa hasil olahan dengan penambahan Saccaromycescerevisiae (konsentrasi 0\%, 2\%, 4\%, 6\%, dan 8\%)

kan di Laboratorium Analisis Makanan dan Minuman Universitas Setia Budi Surakarta, terhadap penentuan kadar asam lemak bebas dan angka peroksida pada minyak didapatkan hasil sebagai berikut :

\section{a. Hasil Uji Organoleptis}

Hasil penelitian didapatkan hasil uji organo- leptis pada sampel Tabel 1 .

\section{b. Hasil Penentuan Kadar Asam Lemak Bebas pada Minyak}

Penentuan kadar asam lemak bebas pada minyak didapatkan hasil di Tabel 2.

Gambar 2 memperlihatkan diagram kadar Asam Lemak Bebas pada minyak kelapa hasil 
Tabel 2. Hasil Penetapan Kadar Asam Lemak Bebas pada Minyak

\begin{tabular}{|c|c|c|c|c|c|}
\hline Sampel & $\begin{array}{c}\text { Berat } \\
\text { Bahan }(g)\end{array}$ & $\begin{array}{l}\text { Vol NaOH } 0,05 \\
\quad \mathrm{~N}(\mathrm{ml})\end{array}$ & $\begin{array}{c}\text { Rerata } \\
\text { Vol.Titra } \\
\mathrm{n}(\mathrm{ml})\end{array}$ & $\begin{array}{c}\text { Asam } \\
\text { Lemak } \\
\text { Bebas (\%) }\end{array}$ & $\begin{array}{c}\text { Rerata Asam } \\
\text { Lemak Bebas } \\
(\%)\end{array}$ \\
\hline A & $\begin{array}{l}5,0786 \\
5,1897 \\
5,4315\end{array}$ & $\begin{array}{l}2,50 \\
2,50 \\
2,50\end{array}$ & 2,50 & $\begin{array}{l}0,98 \\
0,96 \\
0,92\end{array}$ & 0,95 \\
\hline $\mathrm{B}_{0}$ & $\begin{array}{l}5,3341 \\
5,0868 \\
5,3201\end{array}$ & $\begin{array}{l}2,00 \\
1,90 \\
1,80\end{array}$ & 1,90 & $\begin{array}{l}0,74 \\
0,74 \\
0,67\end{array}$ & 0,71 \\
\hline $\mathrm{B}_{2}$ & $\begin{array}{l}5,0858 \\
5,1759 \\
5,5958\end{array}$ & $\begin{array}{l}1,70 \\
1,70 \\
1,70\end{array}$ & 1,70 & $\begin{array}{l}0,66 \\
0,65 \\
0,60\end{array}$ & 0,63 \\
\hline $\mathrm{B}_{4}$ & $\begin{array}{l}5,0148 \\
5,1449 \\
5,0993\end{array}$ & $\begin{array}{l}1,60 \\
1,60 \\
1,60\end{array}$ & 1,60 & $\begin{array}{l}0,63 \\
0,62 \\
0,62\end{array}$ & 0,62 \\
\hline $\mathrm{B}_{6}$ & $\begin{array}{l}5,1019 \\
5,0960 \\
5,2095\end{array}$ & $\begin{array}{l}1,50 \\
1,50 \\
1,50\end{array}$ & 1,50 & $\begin{array}{l}0,58 \\
0,58 \\
0,57\end{array}$ & 0,57 \\
\hline $\mathrm{B}_{8}$ & $\begin{array}{l}5,2610 \\
5,5101 \\
5,7610\end{array}$ & $\begin{array}{l}1,40 \\
1,40 \\
1,40\end{array}$ & 1,40 & $\begin{array}{l}0,53 \\
0,50 \\
0,48\end{array}$ & 0,50 \\
\hline
\end{tabular}

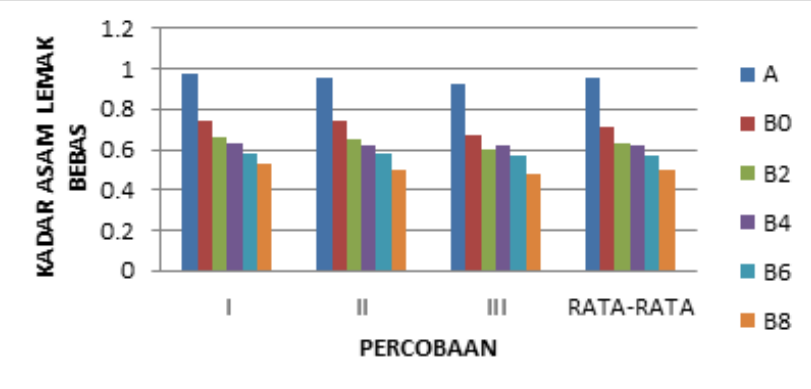

Gambar 2. Diagram Kadar Asam Lemak Bebas

olahan tradisional dan olahan dengan penambahan Saccaromyces cereviseae (konsentrasi $0 \%, 2 \%, 4 \%, 6 \%$, dan $8 \%$ )

\section{c. Hasil Penentuan Kadar Angka Peroksida pada Minyak}

Penentuan angka peroksida pada minyak didapatkan hasil di Tabel 3.

Diagram hasil penentuan angka Peroksida pada minyak kelapa hasil olahan tradisional dan olahan dengan penambahan Saccaromyces cereviseae (konsentrasi 0\%, 2\%, 4\%,6\%, dan $8 \%$ ) disajikan di Gambar 3 :

\section{d. Grafik Penentuan Kadar Asam Lemak}

\section{Bebas}

Hasil penetapan kadar asam lemak bebas dapat ditunjukan dengan grafik penelitian Gambar 4. Berdasarkan grafik tersebut dapat disimpulkan bahwa terjadi penurunan kadar asam lemak bebas setelah dilakukan penam- bahan dengan Saccharomyces cereviseae.

e. Grafik Penentuan Kadar Angka Peroksida Hasil penetapan kadar angka peroksida dapat ditunjukan dengan grafik penelitian Gambar 5. Bedasarkan grafik tersebut dapat disimpulkan bahwa terjadi penurunan kadar asam lemak bebas setelah dilakukan penambahan dengan Saccharomyces cereviseae.

\section{PEMBAHASAN}

Berdasarkan hasil penelitian penentuan kadar asam lemak bebas dengan metode alkalimetri setelah dilakukan uji beda dengan menggunakan statistik ANOVA satu jalan menunjukkan adanya pengaruh yang signifikan terhadap kadar asam lemak pada minyak kelapa hasil olahan tradisional dan hasil olahan dengan penambahan Saccharomyces ceeviseae. Hal ini menunjukan pengaruh yang signifikan di mana nilai signifikasi lebih kecil dari 0,05. Kadar 
Tabel 3. Hasil Penetapan Angka Peroksida pada Minyak

\begin{tabular}{|c|c|c|c|c|c|}
\hline Sampel & $\begin{array}{c}\text { Berat Bahan } \\
(\mathrm{g})\end{array}$ & $\begin{array}{c}\text { Vol.Titran } \\
\mathrm{Na}_{2} \mathrm{~S}_{2} \mathrm{O}_{3} 0,01 \mathrm{~N} \\
(\mathrm{ml})\end{array}$ & $\begin{array}{l}\text { Rata-rata } \\
\text { Vol.Titran } \\
\quad(\mathrm{ml})\end{array}$ & $\begin{array}{c}\text { Angka Peroksida } \\
\text { (mg oksigen } \\
/ 100 \mathrm{~g})\end{array}$ & $\begin{array}{c}\text { Rata-rata Angka } \\
\text { Peroksida (mg } \\
\text { oksigen } \\
/ 100 \mathrm{~g})\end{array}$ \\
\hline A & $\begin{array}{l}5,2380 \\
5,1657 \\
5,1936\end{array}$ & $\begin{array}{l}0,21 \\
0,20 \\
0,19\end{array}$ & 0,20 & $\begin{array}{l}0,92 \\
0,89 \\
0,84\end{array}$ & 0,88 \\
\hline $\mathrm{B}_{0}$ & $\begin{array}{l}5,1246 \\
5,1811 \\
5,0139\end{array}$ & $\begin{array}{l}0,19 \\
0,18 \\
0,17\end{array}$ & 0,18 & $\begin{array}{l}0,85 \\
0,79 \\
0.77\end{array}$ & 0,80 \\
\hline $\mathrm{B}_{2}$ & $\begin{array}{l}5,0350 \\
5,0190 \\
5,0010\end{array}$ & $\begin{array}{l}0,16 \\
0,15 \\
0,14\end{array}$ & 0,15 & $\begin{array}{l}0,73 \\
0,68 \\
0,64\end{array}$ & 0,68 \\
\hline $\mathrm{B}_{4}$ & $\begin{array}{l}5,0182 \\
5,0617 \\
5,2673\end{array}$ & $\begin{array}{l}0,14 \\
0,13 \\
0,13\end{array}$ & 0,13 & $\begin{array}{l}0,69 \\
0,59 \\
0,56\end{array}$ & 0,61 \\
\hline $\mathrm{B}_{6}$ & $\begin{array}{l}5,0952 \\
5,0464 \\
5,1960\end{array}$ & $\begin{array}{l}0,12 \\
0,11 \\
0,11\end{array}$ & 0,11 & $\begin{array}{l}0,54 \\
0,50 \\
0,48\end{array}$ & 0,50 \\
\hline $\mathrm{B}_{8}$ & $\begin{array}{l}5,0553 \\
5,0884 \\
5,1907\end{array}$ & $\begin{array}{l}0,10 \\
0,10 \\
0,10\end{array}$ & 0,10 & $\begin{array}{l}0,45 \\
0,45 \\
0,44\end{array}$ & 0,44 \\
\hline
\end{tabular}

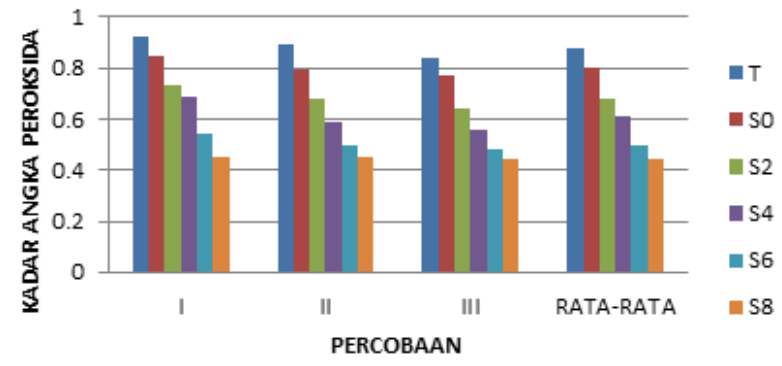

Gambar 3. Diagram Angka Peroksida

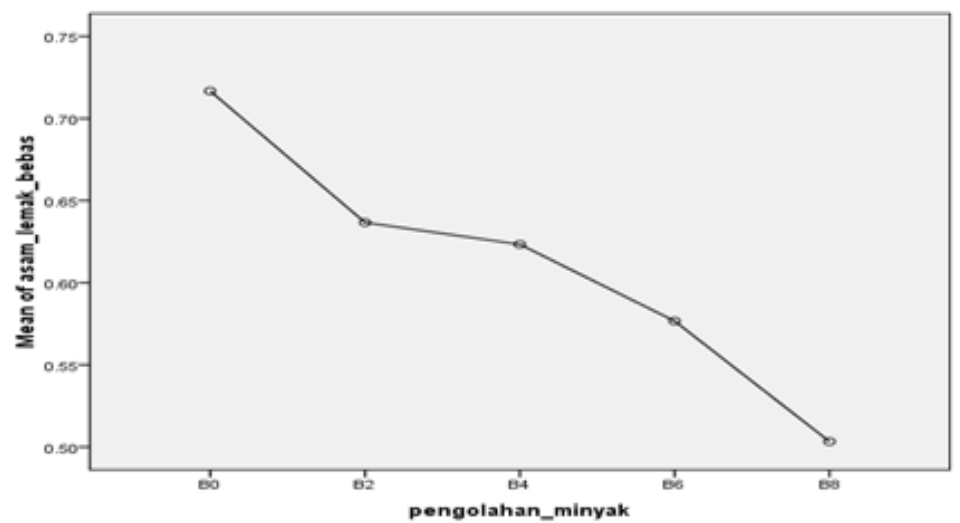

Gambar 4. Grafik Penentuan Kadar Asam Lemak Bebas

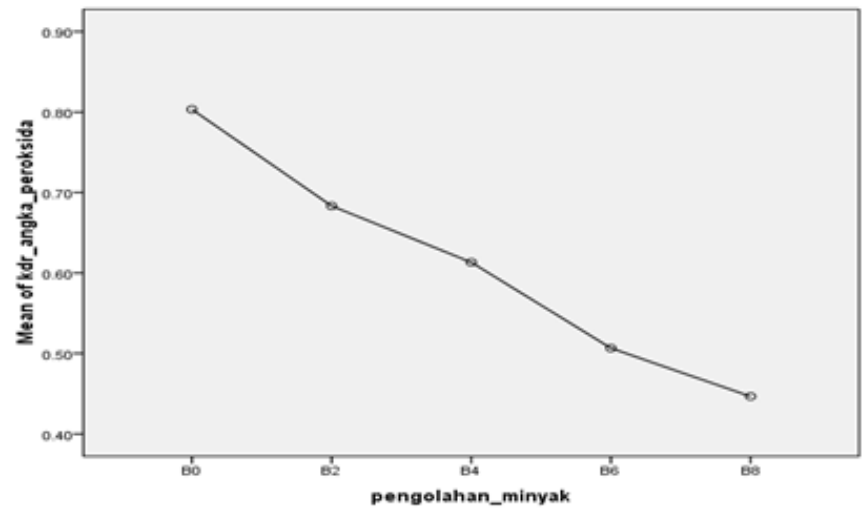

Gambar 5. Grafik Penentuan Kadar Angka Peroksida 
asam lemak bebas pada minyak kelapa hasil olahan tradisional mempunyai kadar yang lebih tinggi sedangkan kadar asam lemak bebas minyak kelapa hasil olahan dengan penambahan Saccharomyces cereviseae mengalami penurunan kadar asam lemak bebas.

Pada penentuan kadar angka peroksida dengan metode iodimetri hasil penelitian setelah dilakukan uji beda dengan menggunakan statistik ANOVA satu jalan tidak menunjukkan adanya pengaruh yang signifikan terhadap kadar angka peroksida pada minyak kelapa hasil olahan tradisional dan hasil olahan dengan penambahan Saccharomyces cereviseae. Hal ini menunjukan tidak ada pengaruh yang signifikan di mana nilai signifikasi lebih besar dari 0,05 .

Minyak dan lemak merupakan substansi dari tumbuh-tumbuhan dan binatang yang bersifat tidak larut dalam air. Keduanya terutama terdiri atas ester gliseraldehid dan asam lemak, yang disebut trigliserida. Lemak terutama digunakan untuk menunjukkan bahwa pada suhu kamar trigliseridanya berbentuk padat, sedangkan minyak pada keadaan yang sama trigliseridanya dalam keadaan cair. (Ketaren, 2016) Pada minyak kelapa hasil olahan tradisional memiliki kadar asam lemak bebas dan angka peroksida lebih tinggi dibandingkan dengan minyak kelapa hasil olahan dengan penambahan Saccharomyces cereviseae. Penambahan Saccharomyces cereviseae mempengaruhi kedua kadar tersebut dikarenakan Saccharomyces cereviseae mempunyai enzim proteolitik yang mempengaruhi proses hidrolisa minyak sehingga kadarnya mengalami penurunan. Pada asam lemak bebas semakin tinggi kadar asam lemak bebasnya maka semakin rendah kualitas minyaknya. Sedangkan pada angka peroksida tingginya angka peroksida disebabkan karena pemanasan minyak kelapa hasil olahan tradisional lebih lama sehingga mempercepat reaksi oksidasi. Sedangkan angka peroksida pada minyak kelapa hasil olahan dengan penambahan Saccharomyces cerevisiae mengalami penurunan hal ini disebabkan semakin banyak Saccharomyces cerevisiae yang ditambahkan maka semakin banyak minyak yang dipisahkan sehingga proses pemanasan menjadi lebih singkat. Adanya air dalam proses hidrolisis akan menghasilkan asam lemak bebas dan gliserol. Asam lemak yang dibebaskan dapat teroksidasi membentuk peroksida. (Ketaren, 2016; Murdijati, 2012)

\section{KESIMPULAN}

Makin tinggi konsentrasi penambahan Saccharomyces cereviseae dalam pembuatan minyak kelapa maka makin kecil kadar asam lemak bebas dan angka peroksida yang dihasilkan.

Kadar asam lemak bebas dan angka peroksida pada minyak kelapa hasil olahan tradisional dan minyak kelapa hasil olahan dengan penambahan Saccharomyces cerevisiae (konsentrasi $0 \%, 2 \%, 4 \%, 6 \%$, dan 8\%) memenuhi standart mutu minyak kelapa dari SNI 7381: 2008.

\section{DAFTAR PUSTAKA}

Anonim. 2008. Standard Nasional Indonesia 7381:2008.

Minyak Kelapa Virgin (VCO). Jakarta: Badan Standarisasi Nasional.

Buckle, KA Edward R. A, Fled G. H, Watton M., Alih Bahasa Hari Purnomo. 1997. Ilmu Pangan. Jakarta: Univeritas Indonesia.

Ketaren, S. 2016. Minyak dan Lemak Pangan. Jakarta: Universitas Indonesia.

Murdijati, G, Pudji Hastuti. S, Supriyanto. 2012. Minyak (Sumber, Penanganan, Pengolahan, dan Pemurnian). Yogyakarta: Universitas Gajah Mada.

Rindengan dan Novarianto. 2005. Pembuatan dan Pemanfaatan Minyak Kelapa Murni. Depok: Penebar Swadaya.

Sutarmi, Hartin. R. 2006. Taklukan Penyakit dengan VCO. Jakarta: Penebar Swadana 